\title{
Sosialisasi Penerapan Aplikasi Smart RT Membantu Pemantauan Covid-19 Di Kelurahan Manukan Kulon, Kecamatan Tandes, Kota Surabaya
}

\author{
Kukuh Primananda Putra ${ }^{1}$, Tjatursari Widiartin ${ }^{2}$ \\ ${ }^{1,2}$ Program Studi Informatika, Fakultas Teknik, Universitas Wijaya Kusuma Surabaya, Surabaya, \\ Indonesia \\ Email: ${ }^{1}$ kukuhprimananda2000@gmail.com, ${ }^{2}$ widiartin@ gmail.com
}

\begin{abstract}
Many Indonesians have been exposed to the corona virus (COVID-19). COVID-19 itself first occurred in the city of Wuhan, the capital of China's Hubei province and has since spread globally, [1]. The Indonesian people need information in the form of monitoring the spread of COVID-19 in real-time. For now, the technology that can be achieved by all and the most widely used is web-based. need the web to find information about COVID-19 cases from various accurate sources. After entering data into the website, people can use it, the Smart RT web runs in real-time. in several trials that will be carried out by the RT 13 community, namely by using the site as a means of COVID-19 information, and the RT 13 community tends to be able to anticipate the spread of COVID-19
\end{abstract}

Keywords: COVID-19, Community, Smart RT.

\begin{abstract}
Abstrak
Banyak masyarakat Indonesia yang terpapar virus corona (COVID-19). COVID-19 sendiri pertamakali terjadi di kota Wuhan, ibukota provinsi Hubei China dan sejak itu itu menyebar secara global, (Nur et al., 2020). Masyarakat Indonesia membutuhkan informasi berupa pemantauan penyebaran COVID-19 secara real-time. Untuk saat ini teknologi yang dapat dijangkau semua dan paling banyak digunakan yaitu berbasis web. Diperlukannya web untuk mencari informasi mengenai kasus COVID-19 dari berbagai sumber yang akurat. setelah memasukan data ke website masyarakat dapat menggunakanya, web Smart RT berjalan secara real-time. di lakukan beberapa uji coba yang akan dilakukan oleh masyarakat RT 13 yaitu dengan, menggunakan website sebagai salah satu sarana informasi COVID-19, dan masyrakat RT 13 cenderung dapat mengantisipasi penyebaran COVID-19
\end{abstract}

Kata Kunci : COVID-19, Masyarakat, Smart RT

\section{A. PENDAhuluan}

Banyak masyarakat Indonesia yang terpapar virus corona 2019 (COVID-19). COVID-19 sendiri pertamakali terjadi di kota Wuhan, ibukota provinsi Hubei China dan sejak itu itu menyebar secara global, (Nur et al., 2020). Indonesia sendiri pertama kali mengkonfirmasi kasus COVID-19 yaitu pada senin 2 maret lalu di sebuah klub dansa Jakarta pada 14 februari, yang diumumkan secara resmi oleh pemerintah. Dua warga Indonesia yang positif mengatakan bahwa melakukan kontak langsung dengan warga Negara Jepang yang sedang berkunjung ke Indonesia. Tanggal 11 maret 2020(Sukur et al., 2020).
COVID-19 sendiri dapat dicegah dengan beberapa cara yaitu dengan membatasi mobilisasi masyarakat yang beresiko terkena. Pencegahan lainnya adalah dengan meningkatkan daya tahan tubuh dengan salah satunya melalui makanan yang sehat yang dapat meningkatkan imun tubuh, memperbanyak cuci tangan, mengunakan hand sanitizer, menggunakan masker, olah raga, menghindari tempat padat, istirahat cukup, dan bila sakit segera berobat ke rumah sakit rujukan untuk evaluasi(Davies, 2002). Dalam upaya mengendalikan penyebaran COVID-19, pemerintah melaksanakan pemberlakuan pembatasan kegiatan masyrakat atau biasa dikenal PPKM. Pemberlakuan kegiatan masyarakat (PPKM) dilakukan di beberapa kota bertujuan 
untuk mengurangi dampak penyebaran COVID19(Napitu et al., 2021).

Masyarakat Indonesia membutuhkan informasi berupa pemantauan penyebaran COVID-19 secara real-time. Untuk saat ini teknologi yang dapat dijangkau semua dan paling banyak digunakan yaitu berbasis web. Diperlukannya web untuk mencari informasi mengenai kasus COVID-19 dari berbagai sumber yang akurat. Namun untuk dapat digunakan masyarakat khususnya masyarakat Indonesia yang gemar bermain smartphone diperlukan web yang juga dapat diakses melalui smartphone maka dari itu diperlukan website yang dapat diakses oleh masyarakat(Alfaridzi \& Premana, 2021).

Salah satu penyebab masyarakat tertular COVID19 adalah padatnya populasi sehingga dapat menyebabkan masyarakat sekitar tertular COVID19, hal ini dapat terjadi di karenakan kurangnya informasi yang di dapat oleh masyarakat sekitar, maka dari itu saya merancang sebuah website yang dapat di akses oleh masyarakat, berupa beberapa informasi mengenai siapa saja yang terpapar COVID-19 pada rumah tersebut sehingga masyarakat dapat lebih waspada.

\section{B. PELAKSAAAN DAN METODE}

Pada penelitian kali ini menggunakan metode survey, metode survey adalah metode penelitian yang digunakan untuk memperoleh data. Untuk lokasi penelitian bertempatan pada RT 13, RW 7, Kelurahan Manukan Kulon, Kecamatan Tandes, Kota Surabaya yang dilakukan pada 1 - 8 Agustus 2021.

Untuk sumber data penelitian yang di gunakan yaitu primer dan sekunder. Data primer adalah data yang dikumpulkan oleh peneliti sendiri atau dirinya sendiri. Ini adalah data yang belum pernah dikumpulkan sebelumnya, baik dengan cara tertentu atau pada periode waktu tertentu Data seunder adalah data yang dikumpulkan oleh orang lain, bukan peneliti itu sendiri. Data ini biasanya berasal dari penelitian lain yang dilakukan oleh lembaga-lembaga atau organisasi seperti BPS dan lain-lain.(Masruroh, 2013). Sedangkan untuk Tehnik pengumpulan data menggunakan observasi dan wawancara,

Pada penelitian ini dilakukan survey dan wawancara kepada ketua RT 13, RW 7, Kelurahan Manukan Kulon, Kecamatan Tandes, Kota Surabaya, dengan tujuan untuk mendapatkan data berupa informasi mengenai siapa saja warga yang terpapar COVID-19, setelah mendapat kan data berupa informasi tersebut akan diproses terlebih dahulu yang nantinya akan di terapkan pada website smartRT, setelah memasukan data ke website masyarakat dapat menggunakanya, web smartRT berjalan secara real-time.

\section{HASIL DAN PEMBAHASAN}

Bagian hasil dan pembahasan berisi paparan hasil kegiatan pengabdian masyarakat analisis yang berkaitan dengan tujuan kegiatan. Setiap hasil pengabdian masyarakat harus dibahas. Pembahasan berisi pemaknaan hasil dan pembandingkan dengan teori dan/atau hasil penelitian/hasil kegiatan pengabdian kepada masyarakat lain yang relevan. Panjang paparan hasil dan pembahasan $40-60 \%$ dari total panjang artikel. Hasil pengabdian masyarakat dapat dilengkapi dengan tabel, grafik (gambar), dan/atau bagan. [Arial, 11]

Pada penelitian kali ini menghasilkan website untuk masyarakat RT 13 yang dapat diakses oleh semua, Untuk Desain sendiri dapat dilihat pada Gambar 1, Di dalam desain akan ada beberapa denah rumah pada RT 13 sesuai data yang diberikan oleh ketua RT.

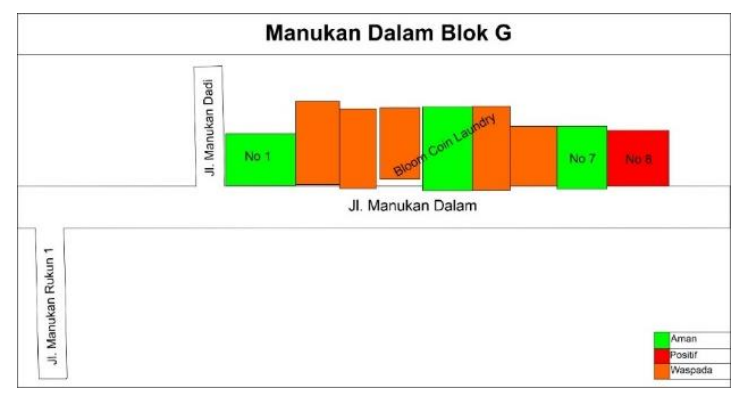

Gambar 1. Desain Website

Untuk mengetahui informasi apakah ada masyarakat yang terpapar COVID-19, pada denah rumah akan berwarna merah menandakan positif, hijau menandakan aman, orange menandakan waspada

Gambar 1 hanya menampilkan denah RT 13 pada blok $\mathrm{G}$ saja dan untuk keseluruhan denah RT 13 dapat dilihat pada Gambar 2,

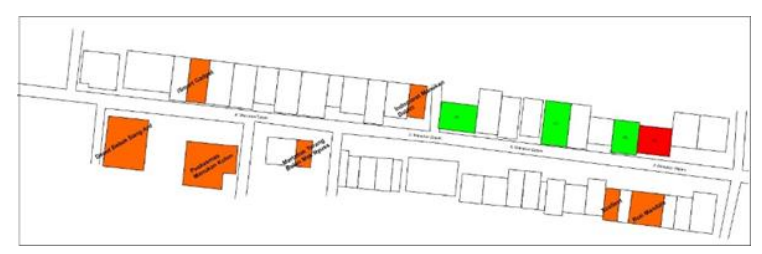

Gambar 2. Denah seluruh RT

Keseluruhan denah RT 13 dapat dilihat pada Gambar 2, pada denah keseluruhan RT 13 pengertian masih sama seperti Gambar 1 yaitu, hijau menandakan aman, merah menandakan positif, sedangkan orange menandakan waspada. 
Untuk langkah selanjutnya denah akan di masukkan ke dalam web.

Untuk selanjutnya adalah pembuatan web, menu utama dapat dilihat pada Gambar 3 dan 4, sedangkan untuk halaman informasi mengenai COVID-19 dapat dilihat pada Gambar 5 sedangkan untuk halaman tersedia menu ketentuan layanan, kebijakan privasi, disclaimer, kontak, dan tentang aku.

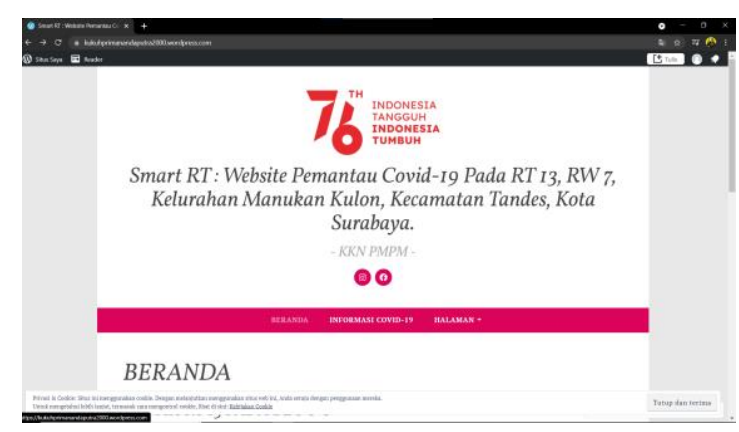

Gambar 3. Menu Utama

Pada Gambar 3 terdapat judul dan menu utama, untuk isinya sendiri terdapat pada Gambar 4.

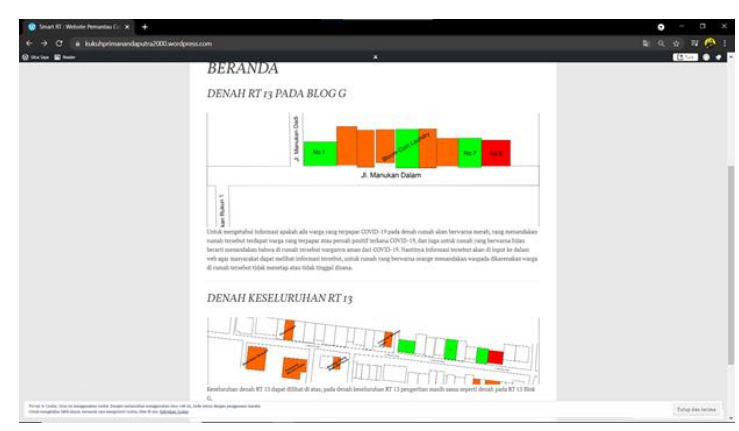

Gambar 4. Denah Sub RT

Gambar 4 menunjukan denah RT 13 yang dibagi menjadi beberapa bagian seperti, denah RT pada blok g, dan juga terdapat denah keseluruhan RT 13.

Untuk tampilan Informasi COVID-19 dapat dilihat pada Gambar 5, yang menunjukan tentang informasi mengenai COVID-19 mengenai kecamatan manukan kulon secara real-time.

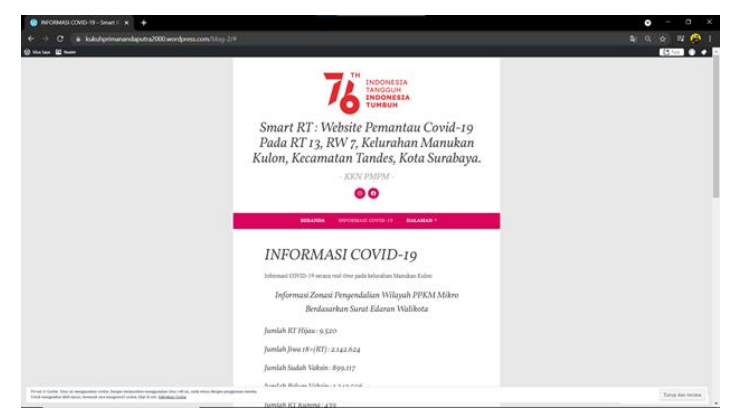

Gambar 5. Informasi Covid 19 secara real time

Untuk hasil di lakukan beberapa uji coba yang akan dilakukan oleh masyarakat RT 13 yaitu dengan, menggunakan website sebagai salah satu sarana informasi COVID-19, dan masyrakat RT 13 cenderung dapat mengantisipasi penyebaran COVID-19 dari biasanya, untuk mengantisipasi tempat-tempat yang rawan terjadi COVID-19 seperti tempat ramai, dan juga masyarakat jadi lebih update informasi mengenai COVID-19, karena adanya web yang membantu masyarakat mendapatkan informasi mengenai COVID-19 secara real-time.

Untuk teknik penulisan data covid ditulis didalam menggunakan tabel seperti ditunjukkan pada tabel 1.

Tabel 1. Teknik penulisan data COVID 19

\begin{tabular}{|l|l|l|l|l|l|l|l|}
\hline No & 1 & 2 & 3 & 4 & 5 & 7 & 8 \\
\hline Positif & & & & & & & \\
\hline Sembuh & & & & & & & \\
\hline Meninggal & & & & & & & \\
\hline
\end{tabular}

\section{Kutipan dan Acuan}

Salah satu ciri artikel ilmiah adalah menyajikan gagasan orang lain untuk memperkuat memperkaya gagasan penulisnya. Gagasan yang telah lebih dulu diungkapkan orang lain ini di acu (dirujuk), dan sumber acuanya dimasukkan dalam daftar pustaka.

Daftar pustaka harus lengkap dan sesuai dengan acuan yang disajikan dalam batang tubuh artikel. Artinya, sumber yang ditulis dalam daftar pustaka benar-benar dirujuk dalam tubuh artikel.

Sebaliknya, semua acuan yang telah disebutkan dalam artikel harus dicantumkan dalam daftar pustaka, Untuk menunjukkan kualitas artikel ilmiah, daftar yang dimasukkan dalam daftar pustaka harus cukup banyak. Daftar pustaka disusun secara alfabetis dan cara penulisannya kutipan, acuan, dan daftar pustaka mengikuti template artikel ini.

Penyajian gagasan orang lain di dalam artikel dilakukan secara tidak langsung. Sebagai contoh, Suharno (1973) menyatakan bahwa kecepatan terdiri dari gerakan ke depan sekuat tenaga dan semaksimal mungkin, kemampuan gerakan kontraksi putus-putus otot atau segerombola otot, kemampuan reaksi otot atau segerombolan otot dalam tempo cepat karena rangsangan. 
Acuan adalah penyebutan sumber gagasan yang dituliskan di dalam teks sebagai (1) pengakuan kepala pemilik gagasan bahwa penulis telah melakukan "peminjaman" bukan penjiplakan, dan (2) pemberitahuan kepada pembacanya siapa dan darimana gagasan tersebut diambil. Acuan memuat nama pengarang yang pendapatnya dikutip tahun sumber informasi ditulis, dan/tanpa nomor halaman tempat informasi yang dirujuk diambil. Nama pengarang yang digunakan dalam acuan hanya nama akhir. Acuan dapat dituliskan di tengah kalimat atau di akhir kalimat kutipan.

Acuan ditulis dan di pisahkan dari kalimat kutipan dengan kurung buka an kurung tutup (periksa contoh-contoh dibawah ini). Acuan yang dituliskan di tengah kalimat dipisahkan dengan kata yang mendahului dan kata yang mengikutinya dengan jarak. Acuan yang dituliskan di akhir kalimat dipisahkan dari kata terkhir kalimat kutipan dengan diberi jarak, namun tidak dipisahkan dengan titik. Nama pengarang ditulis tanpa jarak setalah tanda kurung pembuka dan diikuti koma. Tahun penerbitan dituliskan setelah koma dan diberi jarak. Halaman buku atau artikel setelah tahun penerbitan, dipisahkan dengan tanda titik dua tanpa jarak, dan ditutup dengan kurung tanpa jarak. Sebagai contoh: karya tulis ilmiah adalah tulisan faktual yang digunakan penulisnya untuk memberikan suatu pengetahuan/ informasi kepada orang lain (Riebel, 1978).

Apabila nama pengarang telah disebutkan di dalam teks, tahun penerbitan sumber informasi dituliskan segera setelah nama penulisnya. Atau, apabila nama pengarang tetap ingin disebutkan, acuan ini dituliskan di akhir teks. Contohnya: menurut Riebel (1978), karya tulis ilmiah adalah tulisan faktual yang digunakan penulisnya untuk memberikan suatu pengetahuan /informasi kepada orang lain.

Nama dua pengarang dalam karya yang sama disambung dengan kata 'dan'. Titik koma (;) digunakan untuk dua pengarang atau lebih dari dua pengarang dengan karya yang berbeda. Contohnya: karya tulis ilmiah adalah tulisan faktual yang digunakan penulisnya untuk memberikan suatu pengetahuan /informasi kepada orang lain (Riebel dan Roger, 1980). Jika melibatkan dua pengarang dalam dua karya yang berbeda, contoh penulisnnya: karya tulis ilmiah adalah karya tulis faktual uang digunakan penulisnya untuk memberikan suatu pengetahuan/informasi kepada orang lain (Riebel, 1978; Roger, 1981)

Apabila pengarang lebih dari dua orang, hanya nama pengarang pertama yang dituliskan. Nama pengarang selebihnya digantikan dengan'dkk' (dan kawan-kawan). Tulisan 'dkk' dipisahkan dari nama pengarang, yang diebutkan dengan jarak, diikuti titik, dan diakhiri dengan koma. Contonya: membaca adalah kegiatan interaksi antara pembaca dan penulis yang kehadirannya diwakili oleh teks (Susanto dkk., 1994).

\section{PENUTUP}

\section{Simpulan}

Setelah dilakukan penelitian tentang web Smart RT sebagai salah satu media infromasi COVID-19, maka dapat disimpulkan bahwa ternyata Smart RT dapat meningkatkan kewaspadaan masyarakat terhadap COVID-19, dan masyarakat khusus nya warga RT 13 lebih aktif memberikan informasi apabila terdapat masyarakat yang terpapar COVID-19.

Simpulan menyajikan ringkasan dari uraian hasil dan pembahasan, mengacu pada permasalahan mitra. Berdasarkan kedua hal tersebut, uraikan faktor pendukung dan penghambat kegiatan.Saran web Smart RT sebagai salah satu media infromasi COVID-19 dapat dikembangkan ke tingkat yang lebih luas lagi, yaitu tingkat RW maupun Desa.

Sehingga data sebaran penderita COVID 19 real lebih banyak diketahui masyarakat, dan lebih bermanfaat bagi Masyarakat luas.

\section{E. DAFTAR PUSTAKA}

Alfaridzi, M. A., \& Premana, A. (2021). Aplikasi Berbasis WEB-Realtime Pemantauan Coronavirus Disease 2019 ( COVID-19 ). 3(01), 50-57.

Davies, P. D. O. (2002). Multi-drug resistant tuberculosis. CPD Infection, 3(1), 9-12.

Masruroh, S. (2013). Pengaruh Assessmen Kelas Terhadap Efektifitas Pembelajaran Pai Di Kelas Viii A Smp Muhammadiyah 4 Gadung Surabaya. Pendidikan, 53(9), 64.

Napitu, U., Corry, \& Matondang, M. K. D. (2021). Sosialisasi pembatasan pelaksanaan kegiatan masyarakat (PPKM) mikro di kelurahan bah Kapul. Community Development Journal, 2(2), 232-241.

Nur, A., Thohari, A., \& Vernandez, A. B. (2020). Aplikasi Monitoring Kasus Coronavirus Berbasis Android. JTET (Jurnal Teknik Elektro Terapan) Polines, 9(1), 12-17.

Sukur, moch halim, Kurniadi, B., Haris, \& N Faradillahisari, R. (2020). Penanganan Pelayanan Kesehatan Di Masa Pandemi Covid-19 Dalam Perspektif Hukum Kesehatan. Journal Inicio Legis, 1(1), 1-17.

Jamaludin, J., \& Romindo, R. (2019). Sistem Informasi Akademik Berbasis Web Menggunakan Metode Waterfall Pada SMA Kemala Bhayangkari I Medan. Prosiding Seminar Nasional Teknologi Informatika (pp. 17-27). Medan: Prosiding Seminar Nasional Teknologi Informatika. 
Niar, H., Sipayung, R., Julyanthry, J., Yendrianof, D., Febrianty, F., \& Jamaludin, J. (2020). Sistem Informasi Bisnis. Medan: Yayasan Kita Menulis.

Romindo, R., \& Ameylia, N. (2019). Sistem Informasi Pengarsipan Pada Kantor Notaris Efrina Nofiyanti Kayadu,SH., M.Kn Berbasis Web Dengan Metode Waterfall. Riset dan E-Jurnal Manajemen Informatika Komputer, 81-85.

Romindo, R., Muttaqin, M., Saputra, D. H., Purba, D. W., Iswahyudi, M., Banjarnahor, A. R., et al. (2019). E-Commerce: Implementasi, Strategi dan Inovasinya. Medan: Yayasan Kita Menulis.

Saputra, D. H., Sutiksno, U., Kusuma, A. H., Romindo, R., Wahyuni, D., Purnomo, A., et al. (2020). Digital Marketing: Komunikasi Bisnis Menjadi Lebih Mudah. Medan: Yayasan Kita Menulis.

https://journal.trunojoyo.ac.id/iniciolegis/article/downlo $\mathrm{ad} / 8822 / 4912$ 